\title{
RTEL1 Gene Mutation
}

National Cancer Institute

\section{Source}

National Cancer Institute. RTEL1 Gene Mutation. NCI Thesaurus. Code C152087.

A change in the nucleotide sequence of the RTEL1 gene. 